Editorial

\title{
Innovation in Propagation of Fruit, Vegetable and Ornamental Plants
}

\author{
Sergio Ruffo Roberto ${ }^{1, *(1)}$ and Ronan Carlos Colombo ${ }^{2}$ \\ 1 Agricultural Research Center, Londrina State University, Celso Garcia Cid Road, km 380, P.O. Box 10.011, \\ Londrina 86057-970, Brazil \\ 2 Agricultural Science Department, Federal Technological University of Parana, \\ Francisco Beltrão 85601-970, Brazil; ronancolombo@utfpr.edu.br \\ * Correspondence: sroberto@uel.br; Tel.: +55-43-3371-4774
}

Received: 22 January 2020; Accepted: 30 January 2020; Published: 9 April 2020

check for updates

\begin{abstract}
There are two primary forms of plant propagation: sexual and asexual. In nature, propagation of plants most often involves sexual reproduction, and this form is still used in several species. Over the years, horticulturists have developed asexual propagation methods that use vegetative plant parts. Innovation in plant propagation has supported breeding programs and allowed the production of high-quality nursery plants with the same genetic characteristics of the mother plant, and free of diseases or pests. The purpose of this Special Issue, "Innovation in Propagation of Fruit, Vegetable and Ornamental Plants", was to present state-of-the-art techniques recently developed by researchers worldwide. The Special Issue has brought together some of the latest research results of new techniques in plant propagation in nine original papers, which deal with a wide range of research activities.
\end{abstract}

Keywords: nursery plants; plant multiplication; seeds; cuttings; budding; grafting; micropropagation; biotechnology

\section{Introduction}

In horticulture, plant propagation plays an important role as the number of plants can be rapidly multiplied retaining desirable characteristics of the mother plants, as well as reducing the bearing age of the plants. Depending on the species, different techniques can be applied to optimize a nursery production system or even to solve a specific propagation difficulty.

In cultivated almond (Prunus dulcis), non-infectious bud-failure (NBF) is a commercially important age-related disorder that results in the failure of new vegetative buds to grow in the spring. The incidence of NBF increases with clone age, including within individual long-lived trees as well as nursery propagation lineages. Consequently, nursery practices emphasize the establishment of foundation-mother blocks, utilizing propagation-wood selected from proven and well-monitored propagation lineages. Commercial propagation utilizes axillary shoot buds through traditional budding or grafting. Thus, to solve this issue, one possibility is to examine NBF development using basal epicormic buds from individual trees of advanced age as an alternative source of foundation stock.

Blueberry (Vaccinium virgatum) traditionally is propagated by softwood, semi-hardwood and hardwood cuttings or even rhizome cuttings of selected clones [1]. Some challenges in this production are a very low rooting percentage in many genotypes, the amount of time required to propagate and commercialize newly-released cultivars for mass propagation [1,2] and phytosanitary problems. In vitro culture (micropropagation) can overcome the limitations of traditional cuttings, presenting an alternative for faster growth throughout the year (with no seasonal effects) without pathogens. 
Seed production in pepper (Capsicum sp.) is achieved by the self-pollination of promising plants to develop true breeding lines. In recent years, there has been an increase in the use of hybrid cultivars because of their higher yields and often unique characteristics. However, seeds from hybrid plants cannot be saved for the next generation since self-progeny would show segregation of desirable traits. Therefore, a clonal propagation protocol could be implemented to enhance profitability of these novel germplasm types [3].

Bacterial wilt is a soil-borne disease of eggplant (Solanum melongena) caused by Ralstonia solanacearum, a highly pathogenic soil-borne bacterium that invades the vascular system of a host plant leading to plant wilting and death. At present, the use of tolerant rootstocks for grafting eggplant varieties is the most effective approach to control bacterial wilt disease [4]. Thus, different grafted combinations of eggplant need to be studied to determine if they affect plant growth and abate the bacterial wilt tolerance of a rootstock upon inoculation with $R$. solanacearum.

The Dragon Tree or Drago (Dracaena draco) is a subtropical ornamental plant used for its medicinal properties. In view of the drastic reduction in the number of individual varieties and the consequent loss of dragon tree genetic diversity caused by absence of natural regeneration, micropropagation offers many advantages because it potentially can facilitate large-scale production of valuable clones and allow plant reintroduction in its natural ecosystem [5-9]. Unfortunately, most of the published protocols have been poorly described, in particular concerning the difficult stage of acclimatization, so it is necessary to develop an efficient procedure for micropropagation and subsequent acclimatization of this species under in vitro culture conditions.

\section{Papers in This Special Issue}

The Special Issue "Innovation in Propagation of Fruit, Vegetable and Ornamental Plants" brings together some of the latest research results of new techniques in this field. It presents nine original papers, which deal with a wide range of research activities.

We can divide the Special Issue in three parts, as follows.

\subsection{Fruit Crops}

The first contribution in this section explored the "Association of Indolebutyric Acid with Azospirillum brasilense in the Rooting of Herbaceous Blueberry Cuttings" by Koyama et al. [10]. The use of plant growth-promoting rhizobacteria (PGPRs) can be a promising biological alternative for increasing the rooting of blueberry (Vaccinium sp.) cuttings [11]. Azospirillum is a genus of PGPRs that inhabits the roots of host plants and provides beneficial effects to the plant under normal growth and/or stress conditions [12]. PGPRs of this genus can increase the fixation of free nitrogen and the production of phytohormones, thus promoting growth in inoculated plants [13].

Studies have shown promising results for association with the PGPR species Azospirillum brasilense, since it promotes root development by increasing the production of hormones, leading to growth and development of plants [14-16]. In this context, the objective of this study was to assess the viability of producing blueberry nursery plants from cuttings using different doses of IBA in association with A. brasilense. The authors found that the application of IBA with the A. brasilense rhizobacteria increased the number of roots of 'Powderblue' blueberry cuttings, while the treatments with indolebutyric acid (IBA) alone and IBA $1000 \mathrm{mg} \mathrm{L}^{-1}+$ A. brasilense increased the root length of the cuttings. However, treatments with IBA and $A$. brasilense combined had no impact on the $\%$ rooted cuttings and $\%$ survival of the cuttings.

The second paper illustrated that "Propagation from Basal Epicormic Meristems Remediates an Aging-Related Disorder in Almond Clones" by Gradziel et al. [17]. The deterioration of clone performance with age has similarly been reported in several crops [18-20] due to genetic [20] or epigenetic [21,22] changes resulting in losses in productivity and/or crop value. Non-infectious bud-failure (NBF) is a disorder of almond (Prunus dulcis) characterized by the failure of terminal vegetative buds to push in the spring [23]. Extensive research has failed to find any association of 
NBF with known pathogens, including viruses and viroids [24-28]. However, the incidence of NBF increases with clone age, including within individual long-lived trees as well as nursery propagation lineages. Thus, the aim of this study was to examine NBF development using basal epicormic buds from individual trees of advanced age as an alternative source of foundation stock, since almond commercial propagation utilizes axillary shoot buds through traditional budding or grafting.

The results of this study showed that the age-related progression of NBF was suppressed in these epicormic meristems, possibly owing to their unique origins and ontogeny. However, the underlying mode of action for suppression remains unknown, and vegetative-progeny testing remains the only effective strategy for identifying suitable commercial propagation clone sources. NBF development in commercial orchards propagated from foundation blocks established from these sources was similarly dramatically suppressed even over the 10- to 20-year expected commercial orchard life. Foundation-stock stability can be further maintained through appropriate management of propagation source trees, which requires accurate knowledge of meristem origin and development.

The third paper concerned the "In Vitro Establishment of 'Delite' Rabbiteye Blueberry Microshoots" by Schuchovski and Biasi [29]. Traditionally, blueberry is propagated by softwood, semi-hardwood and hardwood cuttings [1], or even rhizome cuttings of selected clones [30]. Some challenges in this production are a very low rooting percentage in many genotypes, the amount of time required to propagate and commercialize newly-released cultivars for mass propagation [1,2] and phytosanitary problems. In vitro culture (micropropagation) can overcome the limitations of traditional cuttings, presenting an alternative for faster growth [31]. However, one of the first steps to overcome in this process is the establishment of new explants in vitro. Thereby, 'Delite' rabbiteye blueberry was cultured in vitro with four cytokinins: zeatin (ZEA), 6- $(\gamma-\gamma$-dimethylallylamino)-purine (2iP), 6-benzylaminopurine (BAP) and kinetin (KIN) at eight concentrations $(0,2.5,5,10,20,30,40$ and $50 \mu \mathrm{M}$ ) aimed to establish new explants. Additionally, nine combinations of nitrogen salts were tested, using Woody Plant Medium (WPM) and a modified WPM as the basic medium.

Based on the several combinations of cytokinins and nitrogen salts evaluated in this study, the authors recommended, as an efficient strategy for the in vitro establishment of 'Delite' rabbiteye blueberry, the lowest ZEA concentration $(2.5 \mu \mathrm{M})$, which promoted a high survival rate $(89.7 \%)$ as well as a good response of explants forming new shoots (81.3\%). This concentration yielded 1.3 new shoots per explant, a high shoot length $(13.8 \mathrm{~mm})$ and 10.0 leaves per shoot. Concerning salt composition, the authors recommend the original WPM. An increase or decrease in the $\mathrm{NH}_{4} \mathrm{NO}_{3}$ and $\mathrm{Ca}\left(\mathrm{NO}_{3}\right)_{2}$ concentration did not promote better growth than the original medium.

The fourth contribution was "Pecan Propagation: Seed Mass as a Reliable Tool for Seed Selection" by Poletto et al. [32]. High-quality seedlings are essential in establishing healthy and productive orchards, and studies on new technologies for pecan (Carya illinoinensis (Wangenh) K. Koch) cultivation in subtropical regions have mostly focused on seedling production [33,34]. However, seed sizing is a single technique suggested as an efficient indicator positively correlated with seed physiological quality and plantlet vigor $[35,36]$. In this context, this study evaluated the correlation between seed mass, seed emergence and plantlet vigor in the pecan cultivar Importada, towards producing healthy seedlings for orchard establishment under subtropical climatic conditions.

Among the results reported by the authors, a significant positive correlation between seed mass and plantlet height, stem diameter, emergence rate and number of leaves was observed. Thus, the authors suggested that seed mass can be used as a direct method for seed selection towards production of vigorous pecan seedlings. Therefore, controlled studies-taking into consideration the recalcitrant nature of pecan seeds [37] and the influence of genetic stratification of seed parents on these traits-should be carried out. In addition, an increase in seed mass is usually associated with a decrease in the number of seeds that a plant can produce per unit canopy per year [38]. 


\subsection{Vegetable Crops}

The first contribution in this section explores the topic "A Susceptible Scion Reduces Rootstock Tolerance to Ralstonia solanacearum in Grafted Eggplant" by Huang et al. [39]. The use of tolerant rootstocks for grafting eggplant (Solanum melongena) varieties is the most effective approach to control bacterial wilt disease, caused by Ralstonia solanacearum, an important disease in this crop. However, although a disease-tolerant rootstock can generally improve the tolerance of a susceptible scion [4], the disease tolerance of grafted plants is generally lower than that of self-rooted plants $[40,41]$, which suggests that a susceptible scion may also influence the tolerance level of the rootstock. Thus, the authors aimed in this study to establish different grafted combinations of eggplant and determine if they affect plant growth and decrease the bacterial wilt tolerance of a rootstock upon inoculation with $R$. solanacearum.

The authors found that the use of a susceptible scion in scion/rootstock eggplant grafts contributed to a reduction in rootstock tolerance to $R$. solanacearum. Similar results were previously reported for other plant species, including Capsicum anuum L. and Solanum lycopersicum [42,43], where the use of a susceptible scion on a tolerant rootstock reduced the biological yield of plants to a certain extent when infected with $R$. solanacearum. This phenomenon was documented for eggplant through this study.

The second paper concerned "Aeroponic Cloning of Capsicum spp." by Del Valle-Echevarria et al. [3]. Clonally-propagated pepper hybrids would provide an effective way to immortalize favored hybrid genotypes. There are several cloning techniques available, such as in vitro propagation, which presents some disadvantages. In contrast, aeroponic cloning promises to be a great technique that can be used by pepper enthusiasts since it consists of soilless culture that allows for plant growth in a controlled environment, such as a greenhouse or growth chamber that can be readily available [44]. However, peppers have not been evaluated using this technique. Thus, this study evaluated the suitability of an aeroponic cloning protocol by using five Capsicum spp. cultivars as well as one closely related wild species.

Interesting findings were reported in this study: All domestic species were successfully regenerated under aeroponic conditions but not Capsicum eximium, the wild species. In this context, the success of cloning in all five domesticated Capsicum spp. in aeroponic conditions illustrated that it is a viable option for increasing populations of plants with desirable phenotypic traits for both home and boutique growers. Of the species analyzed, Capsicum annuum peppers had the fastest node formation and obtained a larger volume of roots after node formation as compared to C. baccatum, C. frutescens and C. pubescens. This study presented a cost-effective strategy to clonally propagate peppers for personal, industrial and conservation purposes.

\subsection{Ornalmental and Medicinal Crops}

The first contribution in this section explored "In Vitro Propagation and Acclimatization of Dragon Tree (Dracaena draco)" by Galus et al. [45]. Dracena draco, known as the dragon tree, is a subtropical ornamental species that presents important interest due to its medicinal properties [46], which is prompting innovative approaches for its efficient use in the food industry and in pharmacological applications. In this study, an efficient in vitro procedure was developed for bud induction, rooting of developing shoots and greenhouse acclimatization of young plantlets of dragon tree.

The MS medium [47] was supplemented with different combinations of kinetin (KIN) or 6-benzylaminopurine (BAP) and naphthaleneacetic acid (NAA) or indole-3-butyric acid (IBA). Media were (S1) $1 \mathrm{mg} / \mathrm{L} \mathrm{KIN} \mathrm{and} 1 \mathrm{mg} / \mathrm{L} \mathrm{NAA;} \mathrm{(S2)} 3 \mathrm{mg} / \mathrm{L} \mathrm{KIN} \mathrm{and} 1 \mathrm{mg} / \mathrm{L}$ IAA; (S3) $1 \mathrm{mg} / \mathrm{L} \mathrm{BAP}$ and $2 \mathrm{mg} / \mathrm{L}$ IBA; and (S4) $1 \mathrm{mg} / \mathrm{L} \mathrm{BAP}$ and $1 \mathrm{mg} / \mathrm{L}$ NAA [48], and were used to initiate shoot development on dormant buds recovered from mature $D$. draco trees. Developing shoots were sub-cultured on MS medium containing different concentrations of IBA: (R1) $0 \mathrm{mg} / \mathrm{L} \mathrm{IBA;} \mathrm{(R2)} 0.5 \mathrm{mg} / \mathrm{L} \mathrm{IBA}$; (R3) $1 \mathrm{mg} / \mathrm{L}$ IBA; and (R4) $2 \mathrm{mg} / \mathrm{L}$ IBA.

In this study the authors reported that the best shoot induction and rooting media were S1 and $\mathrm{S} 2$, and R3 and R4, respectively. Dormant buds from one-year-old D. draco plants submitted to this 
in vitro procedure allowed successful recovery of up to eight individuals per explant used. In vitro grown plants were successfully acclimated in the greenhouse. The potential of this in vitro procedure for multiplication of this endangered tree is discussed in this report.

The second paper in this section is "Improved Propagation and Growing Techniques for Oleander Nursery Production" by Sabatino et al. [49]. Implementing propagation methods to enhance transplant success, establishment and post-plant maintenance is a major objective for plant nurseries involved in the production of shrubs to be used for gardens and natural landscapes in regions with a Mediterranean climate. In this regard, the production of oleander (Nerium oleander) rooted cuttings with a well-developed root system is fundamental for successful transplanting and establishment in the field [50]. In the first trial, the authors examined rooting of stem cuttings in relation to number of nodes and indole-3-butyric acid (IBA) treatment in five N. oleander clones (clones 1 to 5) grown in Sicily. In a second trial, they tested the effect of different forcing dates and shading on oleander plants for gardens and natural landscapes using just one clone (clone 1).

Interesting results were recorded in both trials: three- and four-node cuttings, ranging in length from 10 to $14 \mathrm{~cm}$, were significantly superior to two-node cuttings $(8-10 \mathrm{~cm}$ long) in terms of rooting percentage and number of roots per cutting. Concerning IBA application, this treatment improved rooting percentage and root number as compared to an untreated control. However, irrespective of IBA application, rooting percentages ranged from $52 \%$ to $94 \%$ in clones 4 and 1, respectively. With respect to the shading periods, shaded plants forced in October were significantly higher than those forced in November and in December. Beginning of flowering was delayed in unforced plants. Plants forced in October flowered significantly sooner (first decade of March) than unforced ones (first decade of May) and reached complete flowering almost two months earlier (last week of March). Shading might also save a considerable amount of water during the driest months, especially in Mediterranean areas where water is a scarce resource. Finally, by forcing oleander to flower earlier, growers can supply blooming plants to the market when they would naturally still be vegetative. Overall, this would provide nurseries involved in ornamental plant production with a great marketing tool.

The last contribution examined is "LEDs Combined with CHO Sources and CCC Priming PLB Regeneration of Phalaenopsis" by Mehraj et al. [51]. Regeneration of protocorm-like bodies (PLB) is the best and most efficient technique for orchid micropropagation [52], because it has a rapid proliferation capacity for producing a large number of PLBs within a short period [53]. However, environmental factors such as culture media and light source can affect PLB regeneration and plantlet development. Thus, this study determined the best carbohydrate $(\mathrm{CHO})$ source and LED light combination for successful PLB regeneration of Phalaenopsis "Fmk02010". In addition, the authors also assessed the impact of chlorocholine chloride (CCC) priming in in vitro PLB propagation of Phalaenopsis. The authors applied 15 LEDs combined with three $\mathrm{CHO}$ sources and five CCC concentrations to assess the PLB organogenesis.

Among the results, the authors concluded that sucrose and trehalose can be used as excellent CHO sources in the culture media for PLB regeneration of Phalaenopsis. Red/white LED + sucrose was the best combination to produce the maximum number of PLBs. However, the combination of blue/white LED + trehalose also produced a large number with healthier PLBs; it also had a tendency to produce a greater number of shoots that would need immediate subculture for future preservation. Red/blue/white LED + trehalose generated a satisfactory number of PLBs with a higher fresh weight and did not generate any shoots. An excessive concentration of CCC $\left(10 \mathrm{mgL}^{-1}\right)$ caused an enormous reduction in the number of PLBs, the percentage of PLB formation and fresh weight; the addition of low concentrations of CCC in the plant culture medium was also unnecessary.

\section{Conclusions}

The papers of the Special Issue on "Innovation in Propagation of Fruit, Vegetable and Ornamental Plants" represent innovative research results in this area, with strong applications regarding nursery 
production and breeding of these species. We hope that this Special Issue will stimulate further research in this area worldwide.

Author Contributions: The contribution to the programming and executing of this Special Issue must be equally divided by S.R.R. and R.C.C. All authors have read and agreed to the published version of the manuscript.

Funding: This research received no external funding.

Acknowledgments: We thank all authors of the Special Issue.

Conflicts of Interest: The authors declare no conflicts of interest.

\section{References}

1. Marino, S.R.; Williamson, J.G.; Olmstead, J.W.; Harmon, P.F. Vegetative growth of three southern highbush blueberry cultivars obtained from micropropagation and softwood cuttings in two Florida locations. HortScience 2014, 49, 556-561. [CrossRef]

2. Meiners, J.; Schwab, M.; Szankowski, I. Efficient in vitro regeneration systems for Vaccinium species. Plant Cell Tissue Organ Cult. 2007, 89, 169-176. [CrossRef]

3. Del Valle-Echevarria, A.R.; Kantar, M.B.; Branca, J.; Moore, S.; Frederiksen, M.K.; Hagen, L.; Hussain, T.; Baumler, D.J. Aeroponic Cloning of Capsicum spp. Horticulturae 2019, 5, 30. [CrossRef]

4. King, S.R.; Davis, A.R.; Liu, W.; Levi, A. Grafting for disease resistance. HortScience 2008, 43, $1673-1676$. [CrossRef]

5. Miller, L.R.; Murashige, T. Tissue culture propagation of tropical foliage plants. In Vitro Cell. Dev. Biol. Anim. 1976, 12, 797-813. [CrossRef]

6. Vinterhalter, D. In vitro Propagation of Green-Foliaged Dracaena-Fragrans Ker. Plant Cell Tissue Org. 1989, 17, 13-19.

7. Vinterhalter, D.; Vinterhalter, B. Micropropagation of Dracaena Species. In Biotechnology in Agriculture and Forestry; Springer: Berlin/Heidelberg, Germany, 1997; Volume 40, pp. 131-146.

8. Tian, L.; Tan, H.Y.; Zhang, L. Stem segment culture and tube propagation of Dracaena saneriana cv. virscens. Acta Hortic. Sin. 1999, 26, 133-134.

9. Blanco, M.; Valverde, R.; Gomez, L. Micropropagation of Dracaena deremensis. Agron. Costarric. 2004, $28,7-15$.

10. Koyama, R.; Aparecido Ribeiro Júnior, W.; Mariani Zeffa, D.; Tadeu Faria, R.; Mitsuharu Saito, H.; Simões Azeredo Gonçalves, L.; Ruffo Roberto, S. Association of indolebutyric acid with Azospirillum brasilense in the rooting of herbaceous blueberry cuttings. Horticulturae 2019, 5, 68. [CrossRef]

11. Mariosa, T.N.; Melloni, E.G.P.; Melloni, R.; Ferreira, G.M.R.; Souza, S.M.P.; Silva, L.F.O. Rhizobacteria and development of seedlings from semi-hardwood cuttings of olive (Olea europaea L.). Revista de Ciências Agrárias 2017, 60, 302-306. [CrossRef]

12. Khademian, R.; Asghari, B.; Sedaghati, B.; Yaghoubian, Y. Plant beneficial rhizospheric microorganisms (PBRMs) mitigate deleterious effects of salinity in sesame (Sesamum indicum L.): Physio-biochemical properties, fatty acids composition and secondary metabolites content. Ind. Crops. Prod. 2019, 136, 129-139. [CrossRef]

13. Cassán, F.; Diaz-Zorita, M. Azospirillum sp. in current agriculture: From the laboratory to the field. Soil Biol. Biochem. 2016, 103, 117-130. [CrossRef]

14. Molina, R.; Rivera, D.; Mora, V.; López, G.; Rosas, S.; Spaepen, S.; Vanderleyden, J.; Cassán, F. Regulation of IAA biosynthesis in Azospirillum brasilense under environmental stress conditions. Curr. Microbiol. 2018, 75, 1408-1418. [CrossRef] [PubMed]

15. Rivera, D.; Mora, V.; Lopez, G.; Rosas, S.; Spaepen, S.; Vanderleyden, J.; Cassan, F. New insights into indole-3-acetic acid metabolism in Azospirillum brasilense. J. Appl. Microbiol. Biochem. 2018, 125, 1774-1785. [CrossRef]

16. Fukami, J.; Ollero, F.J.; de la Osa, C.; Valderrama-Fernández, R.; Nogueira, M.A.; Megías, M.; Hungria, M. Antioxidant activity and induction of mechanisms of resistance to stresses related to the inoculation with Azospirillum brasilense. Arch. Microbiol. 2018, 200, 1191-1203. [CrossRef]

17. Gradziel, T.; Lampinen, B.; Preece, J.E. Propagation from basal epicormic meristems remediates an aging-related disorder in almond clones. Horticulturae 2019, 5, 28. [CrossRef]

18. Kester, D.E. The clone in Horticulture. HortScience 1983, 18, 831-837. 
19. Skowcroft, W.R. Somaclonal Variation, the Myth of Clonal Uniformity. In Genetic Flux in Plants; Hohn, B., Dennis, E.S., Eds.; Springer: New York, NY, USA, 1985; pp. 217-245.

20. Skirvin, R.M.; McPheeters, K.D.; Norton, M. Sources and frequency of somaclonal variation. HortScience 1994, 29, 1232-1237. [CrossRef]

21. D'Aquila, P.; Rose, G.; Bellizzi, D.; Passarino, G. Epigenetics and aging. Maturitas 2013, 74, 130-136. [CrossRef]

22. Fraga, M.F.; Rodriguez, R.; Canal, M.J. Genomic DNA methylation-demethylation during aging and reinvigoration of Pinus radiata. Tree Physiol. 2002, 22, 813-816. [CrossRef]

23. Kester Dale, E.; Asay, R.N. Variability in noninfectious bud-failure of 'Nonpareil' almond. Location and environment. J. Am. Soc. Hortic. Sci. 1978, 103, 377-382.

24. Fenton, C.A.L.; Kuniyuki, A.H.; Kester, D.E. Search for a viroid etiology for noninfectious bud failure in almond. HortScience 1988, 23, 1050-1053.

25. Kester, D.E.; Gradziel, T.M. Genetic Disorders. In Almond Production Manual; Micke, W.C., Ed.; University of California: Oakland, CA, USA, 1996; pp. 76-87.

26. Kester, D.E. Noninfectious Bud-Failure in Almond. In Virus Diseases and Disorders of Stone Fruits in North America; Fulton, R.W., Ed.; Agricultural Research Service, U.S. Department of Agriculture: Washington, DC, USA, 1976; pp. 278-283.

27. Kester, D.E. Noninfectious bud-failure, a nontransmissable inherited disorder in almond. I. Pattern of phenotypic inheritance. Proc. Am. Soc. Hortic. Sci. 1968, 92, 7-15.

28. Kester, D.E. Noninfectious bud-failure, a nontransmissable inherited disorder in almond II. Progeny tests for bud-failure. Proc. Am. Soc. Hortic. Sci. 1968, 92, 16-28.

29. Schuchovski, C.S.; Biasi, L.A. In Vitro establishment of 'Delite' rabbiteye blueberry microshoots. Horticulturae 2019, 5, 24. [CrossRef]

30. Debnath, S.C. A scale-up system for lowbush blueberry micropropagation using a bioreactor. HortScience 2009, 44, 1962-1966. [CrossRef]

31. Debnath, S.C. Temporary immersion and stationary bioreactors for mass propagation of true-to-type highbush, half-high, and hybrid blueberries (Vaccinium spp.). J. Hortic. Sci. Biotechnol. 2017, 92, 72-80. [CrossRef]

32. Poletto, T.; Stefenon, V.M.; Poletto, I.; Muniz, M.F.B. Pecan propagation: Seed mass as a reliable tool for seed selection. Horticulturae 2018, 4, 26. [CrossRef]

33. Cargnelutti Filho, A.; Poletto, T.; Muniz, M.F.B.; Baggiotto, C.; Poletto, I.; Fronza, D. Sampling design for height and diameter evaluation of pecan seedlings. Ciênc. Rural 2014, 44, 2151-2156. [CrossRef]

34. Poletto, I.; Muniz, M.F.B.; Poletto, T.; Stefenon, V.M.; Baggiotto, C.; Ceconi, D.E. Germination and development of pecan cultivar seedlings by seed stratification. Pesqui. Agropecu. Bras. 2015, 50, 1232-1235. [CrossRef]

35. Pereira, W.A.; Pereira, S.M.A.; Dias, D.C.F.S. Influence of seed size and water restriction on germination of soybean seeds and on early development of seedlings. J. Seed Sci. 2013, 35, 316-322. [CrossRef]

36. Bispo, J.S.; Costa, D.C.C.; Gomes, S.E.V.; Oliveira, G.M.; Matias, J.R.; Ribeiro, R.C.; Dantas, B.F. Size and vigor of Anadenanthera colubrina (Vell.) Brenan seeds harvested in Caatinga areas. J. Seed Sci. 2017, 39, 363-373. [CrossRef]

37. Dalkiliç, Z. Effects of drying on germination rate of pecan seeds. J. Food Agric. Environ. 2013, 11, 879-882.

38. Henery, M.L.; Westoby, M. Seed mass and seed nutrient content as predictors of seed output variation between species. Oikos 2001, 92, 479-490. [CrossRef]

39. Huang, C.; Wang, Y.; Yang, Y.; Zhong, C.; Notaguchi, M.; Yu, W. A Susceptible scion reduces rootstock tolerance to Ralstonia solanacearum in grafted eggplant. Horticulturae 2019, 5, 78. [CrossRef]

40. Nakaho, K.; Inoue, H.; Takayama, T.; Miyagawa, H. Distribution and multiplication of Ralstonia solanacearum in tomato plants with resistance derived from different origins. J. Gen. Plant Pathol. 2004, 70, 115-119. [CrossRef]

41. Seemüller, E.; Harries, H. Plant Resistance. Phytoplasmas: Genomes, Plant Hosts and Vectors; CAB International: Oxfordshire, UK, 2010; pp. 147-169.

42. Liu, Y.; Jiang, F.; Zhang, N.; Wang, H.; Ai, X. Relationship between osmoregulation and bacterial wilt resistance of grafted pepper. Acta Hortic. Sin. 2011, 38, 903-910.

43. McAvoy, T.; Freeman, J.H.; Rideout, S.L.; Olson, S.M.; Paret, M.L. Evaluation of grafting using hybrid rootstocks for management of bacterial wilt in field tomato production. HortScience 2012, 47, 621-625. [CrossRef] 
44. Ritter, E.; Angulo, B.; Riga, P.; Herran, C.; Relloso, J.; San Jose, M. Comparison of hydroponic and aeroponic cultivation systems for the production of potato minitubers. Potato Res. 2001, 44, 127-135. [CrossRef]

45. Galus, A.; Chenari Bouket, A.; Belbahri, L. In Vitro propagation and acclimatization of Dragon Tree (Dracaena draco). Horticulturae 2019, 5, 64. [CrossRef]

46. Jura-Morawiec, J.; Tulik, M. Dragon's blood secretion and its ecological significance. Chemoecology 2016, 26, 101-105. [CrossRef] [PubMed]

47. Murashige, T.; Skoog, F. A Revised Medium for Rapid Growth and Bio Assays with Tobacco Tissue Cultures. Physiol. Plant. 1962, 15, 473-497. [CrossRef]

48. Liu, J.; Deng, M.; Henny, R.J.; Chen, J.; Xie, J. Regeneration of Dracaena surculosa through indirect shoot organogenesis. HortScience 2010, 45, 1250-1254. [CrossRef]

49. Sabatino, L.; D'Anna, F.; Iapichino, G. Improved propagation and growing techniques for oleander nursery production. Horticulturae 2019, 5, 55. [CrossRef]

50. Pilon, P. Perennial Solutions: A Grower's Guide to Perennial Production, 1st ed.; Ball Publishing: Batavia, IL, USA, 2005; p. 546.

51. Mehraj, H.; Alam, M.M.; Habiba, S.U.; Mehbub, H. LEDs Combined with CHO sources and CCC priming PLB regeneration of Phalaenopsis. Horticulturae 2019, 5, 34. [CrossRef]

52. Arditti, J.; Ernst, R. Micropropagation of Orchids; Wiley: New York, NY, USA, 1993; pp. 1-682.

53. Sheelavanthmath, S.S.; Murthy, H.N.; Hema, B.P.; Hahn, E.J.; Paek, K.Y. High frequency of protocorm like bodies (PLBs) induction and plant regeneration from protocorm and leaf sections of Aerides crispum. Sci. Hortic. 2005, 106, 395-401. [CrossRef]

(C) 2020 by the authors. Licensee MDPI, Basel, Switzerland. This article is an open access article distributed under the terms and conditions of the Creative Commons Attribution (CC BY) license (http://creativecommons.org/licenses/by/4.0/). 